\title{
Removal of Ag(I) from Aqueous Solution by Japanese Natural Clinoptilolite
}

\author{
Takaaki Wajima \\ Department of Urban Environment Systems, Graduate School of Engineering, Chiba University, Chiba, Japan \\ Email:wajima@tu.chiba-u.ac.jp
}

How to cite this paper: Wajima, T. (2016) Removal of $\mathrm{Ag}(\mathrm{I})$ from Aqueous Solution by Japanese Natural Clinoptilolite. Advances in Chemical Engineering and Science, 6, 470487.

http://dx.doi.org/10.4236/aces.2016.64042

Received: August 17, 2016

Accepted: October 9, 2016

Published: October 12, 2016

Copyright $\odot 2016$ by author and Scientific Research Publishing Inc. This work is licensed under the Creative Commons Attribution International License (CC BY 4.0).

http://creativecommons.org/licenses/by/4.0/

\begin{abstract}
The present study examined the adsorption of silver ion in aqueous solution onto natural clinoptilolite zeolite from Futatsui Mine, Akita Prefecture, Japan. The effects of various parameters, i.e., solution $\mathrm{pH}$, adsorbent dosage, adsorption time, silver ion solution concentration, and temperature, on silver ion adsorption process onto clinoptilolite were examined. Additionally, the thermodynamics of the silver ion adsorption process was investigated. The optimum $\mathrm{pH}$ for silver adsorption was determined to be around 4.0. The adsorption process could be well described by the Langmuir isotherm model. The calculated maximum adsorption capacity was 0.64 $\mathrm{mmol} / \mathrm{g}$. Adsorption kinetics studies were also conducted. The results showed that the adsorption process preferentially followed the pseudo-second-order kinetics model over the pseudo-first-order model. Furthermore, with decreasing aqueous solution temperatures, the adsorption kinetics became slower and the amount of silver ion adsorbed increased. The thermodynamic values, $\Delta G^{0}, \Delta H^{0}$, and $\Delta S^{0}$, indicated that adsorption was an exothermic and spontaneous process.
\end{abstract}

\section{Keywords}

Clinoptilolite, Ag(I) Removal, Adsorption, Natural Zeolite

\section{Introduction}

The removal of metal ions from industrial wastewaters using different adsorbents is always of great interest [1] [2] because industrial wastewaters often contain considerable amounts of metal ions that could pose a potential threat to the public health and environment if discharged without adequate treatment. High concentrations of problematic metals in solution can affect humans, animals, and vegetation. The pollution of water and soil by metal cations increases proportionally with the expansion of industrial activities [3] [4]. To minimize the costs associated with the treatment of such industrial 
wastewaters, most of the last investigations have focused on the use of low-cost adsorbents [5] [6].

In recent years, the use of natural zeolites to control heavy metal ions pollution of effluents has increased. Natural zeolites have ion-exchange capabilities toward removing metal ions, thus making them suitable for use in wastewater treatment. In addition, natural zeolites are considered to be inexpensive [7] [8]. Zeolites are a naturally occurring crystalline aluminosilicate that consists of a framework of tetrahedral molecules, linked with each other by shared oxygen atoms, exchangeable alkaline and alkaline earth metal cations (typically $\mathrm{Na}^{+}, \mathrm{K}^{+}, \mathrm{Ca}^{2+}, \mathrm{Mg}^{2+}$ ), and water. Additionally, zeolites have a porous structure, enclosing interconnected cavities within which metal ions and water molecules are contained [9]. The fundamental building block of zeolites is a tetrahedron of four oxygen atoms surrounding a relatively small silicon or aluminum atom. Because aluminum has one less positive charge than silicon, the framework has a net negative charge of one at each aluminum atom site and is balanced by the exchangeable cation [10]. Clinoptilolite, thomsonite, gismondine, and gonnardite are common known natural zeolites. Clinoptilolite is the most abundant in nature and has a typical chemical formula of $\mathrm{Na}_{6} \mathrm{Al}_{6} \mathrm{Si}_{30} \mathrm{O}_{72} \cdot 24 \mathrm{H}_{2} \mathrm{O}$ [11] [12]. The chemical, surface, and ionexchange properties of clinoptilolite have been examined in many studies [13]-[16]. For example, the selectivity of $\mathrm{Na}$-form clinoptilolite toward $\mathrm{Pb}^{2+}, \mathrm{Cd}^{2+}, \mathrm{Cs}^{+}, \mathrm{Cu}^{2+}, \mathrm{Co}^{2+}$, $\mathrm{Cr}^{3+}, \mathrm{Zn}^{2+}, \mathrm{N}^{\mathrm{i} 2+}, \mathrm{Hg}^{2+}$ was determined [17].

Silver is commonly used as a raw material in various industries owing to its excellent malleability, ductility, electrical and thermal conductivity, photosensitivity, and antimicrobial properties. Accordingly, copious amounts of silver are lost in the effluents discharged from such industries, and owing to its toxicity to living organisms, the removal of silver from wastewaters is important. Available technologies for the removal of silver include precipitation, electrolysis, and solvent extraction, and processes that use ion exchange resins and chelating agents. These methods can be used profitably on a large scale when metal effluent concentrations are sufficiently high, i.e., >100 ppm [18]-[21]. To minimize processing costs and to reduce the metal concentration in industrial wastewaters, most recent investigations have focused on the use of low-cost adsorbents such as zeolites [22] [23].

Additionally, it has been reported that silver-zeolite composites can inhibit bacterial growth under aerobic [24] and anaerobic conditions [25]. Some of the microorganisms existing in our living environment assist in ecological cycles, while others are responsible for diseases in people, animals, and plants [26]. Microorganism growth and death are influenced by environmental factors such as temperature, $\mathrm{pH}$, oxygen level, pressure, and light irradiation. Antimicrobial agents, such as alcohols, phenols, halogenated compounds, quaternary ammonium salts, heavy metal ions $\left(\mathrm{Ag}^{+}, \mathrm{Zn}^{2+}, \mathrm{Cu}^{2+}, \mathrm{Fe}^{2+/ 3+}\right.$, $\left.\mathrm{Cd}^{2+}, \mathrm{Pd}^{2+}\right)$, silver nanoparticles, metal oxides $\left(\mathrm{ZnO}, \mathrm{MgO}, \mathrm{Ag}_{2} \mathrm{O}\right)$ and zirconium phosphates, and oxidizing agents (ozone, chlorine and its derivates), heat, and UV light are used to prevent contamination or sterilize contaminated materials [27]-[37]. Owing to its broad-spectrum antibacterial and antimicrobial properties, lack of toxicity to hu- 
mans, high degree of biocompatibility, excellent resistance to sterilization conditions, and long-term antibacterial efficiency, silver either in metallic and nanoparticle form or as an ion is the most frequently used antibacterial agent for controlling bacterial growth [27] [31] [36]-[43]. An antibacterial agent such as a silver plate, silver nitrate solution, or silver sulfadiazine could be used directly but is not preferred because of its high cost. Alternatively, preparing antibacterial silver as a supported material with a high specific surface area and porosity is preferable. Examples of carrier support material for silver include polymers [29] [44]-[47], metal oxides [48] [49], silica [50] [51], glass [52] [53], clay [47] [54] [55], synthetic zeolites (such as LTA [44] [56]-[61], LTX [56] [62], LTY [56], and ETS-10 [63]), and natural zeolites (such as mordenite [56] and clinoptilolite [31] [64]-[69]). These exemplified supports are the most common and economical carriers owing to their user-friendly handling, nontoxicity, and controlled long-term release rate.

In the present study, we examined the potential of locally available natural zeolite, clinoptilolite, for the removal of $\mathrm{Ag}^{+}$from aqueous solution and optimization of conditions for its maximum adsorption. The effects of various parameters, i.e., $\mathrm{pH}$, adsorbent dosage, initial solution concentration, reaction time, and temperature, on the $\mathrm{Ag}^{+}$adsorption process were investigated to evaluate the adsorption properties of clinoptilolite as Ag-supported material for use either as a bactericide or for the removal of $\mathrm{Ag}^{+}$from polluted industrial waters. Additionally, the thermodynamics and kinetics of $\mathrm{Ag}^{+}$adsorption onto clinoptilolite were investigated.

\section{Experimental}

\subsection{Zeolite Sample}

The zeolite sample (clinoptilolite) used in this study was obtained from Futatsui mine, Akita prefecture, Japan. Before the experiments, clinoptilolite was ground to a certain particle size $(<250 \mu \mathrm{m})$ and dried at $80^{\circ} \mathrm{C}$ in a drying oven overnight. Table 1 shows the exchangeable cations and cation exchange capacity of clinoptilolite determined using a modified Schollenberger method [70]. The cation exchange capacity $(1.67 \mathrm{mmol} / \mathrm{g})$ is relatively high, and most of the exchangeable cation sites are occupied by $\mathrm{Na}^{+}$and $\mathrm{K}^{+}$.

\subsection{Adsorption Studies}

$\mathrm{Ag}^{+}$solution was prepared from its nitrate salt, $\mathrm{AgNO}_{3}$ (>99\% purity, Wako, Japan), and distilled water. The amount of $\mathrm{Ag}^{+}$adsorbed on unit mass clinoptilolite at equilibrium, $q_{\mathrm{e}}(\mathrm{mmol} / \mathrm{g})$, and the $\mathrm{Ag}^{+}$removal from solution, $R(\%)$, were calculated from changes in the $\mathrm{Ag}^{+}$concentration in the medium by considering the adsorption volume

Table 1. Exchangeable cations and cation exchange capacity of natural clinoptilolite zeolite $(\mathrm{mmol} / \mathrm{g})$.

\begin{tabular}{ccccc}
\hline \multirow{2}{*}{ Cation exchange capacity } & \multicolumn{4}{c}{ Exchangeable cations } \\
\cline { 2 - 5 } & $\mathrm{Na}^{+}$ & $\mathrm{K}^{+}$ & $\mathrm{Mg}^{2+}$ & $\mathrm{Ca}^{2+}$ \\
\hline 1.67 & 0.84 & 0.71 & 0.02 & 0.07 \\
\hline
\end{tabular}


and amount of zeolite sample used:

$$
\begin{gathered}
q_{\mathrm{e}}=\left(C_{\mathrm{i}}-C_{\mathrm{e}}\right) V / m, \\
R=\left(C_{\mathrm{i}}-C_{\mathrm{e}}\right) / C_{\mathrm{i}} \times 100,
\end{gathered}
$$

and $C_{\mathrm{i}}$ and $C_{\mathrm{e}}$ are the $\mathrm{Ag}^{+}$concentrations in the solution before and after adsorption for a certain adsorption time, respectively $(\mathrm{mM}), m(\mathrm{~g})$ is the mass of zeolite, and $V(\mathrm{~L})$ is the Ag solution volume.

\subsubsection{Effect of Solution $\mathrm{pH}$}

The effect of solution $\mathrm{pH}$ on $\mathrm{Ag}$ adsorption was investigated using $0.5 \mathrm{mM} \mathrm{AgNO}_{3}$ solution over a $\mathrm{pH}$ range of $1-8$. The $\mathrm{pH}$ of the $\mathrm{Ag}$ solution was adjusted with $\mathrm{HNO}_{3}$ solution. Adsorption tests were conducted in $50-\mathrm{mL}$ polypropylene centrifuged tubes. In

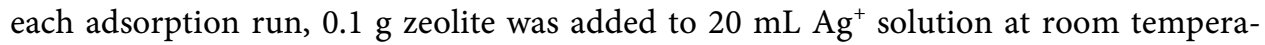
ture, and the tube was shaken using a reciprocal shaker ( $200 \mathrm{rpm}$ ). After $2 \mathrm{~h}$ of mixing, the aqueous phase was separated from the solid (adsorbent) by centrifugation (3000 $\mathrm{rpm}, 10 \mathrm{~min}$ ), the $\mathrm{pH}$ of the supernatant was measured by a $\mathrm{pH}$ meter (Horiba, D-53, Japan) and the concentration of $\mathrm{Ag}^{+}$in the supernatant was determined by inductively coupled plasma-atomic emission spectroscopy (ICP-AES; Seiko, SPS5510, Japan) to determine $q_{\mathrm{e}}$.

\subsubsection{Effect of Adsorbent Dosage}

The effect of adsorbent dosage on $\mathrm{Ag}^{+}$removal was determined using $0.5 \mathrm{mM} \mathrm{AgNO}_{3}$ solution. The zeolite sample at varying amounts of $0.02-0.2 \mathrm{~g}$ was added to $20 \mathrm{~mL} \mathrm{Ag}^{+}$ solution in a tube at room temperature, and the tube was shaken for $2 \mathrm{~h}$ with a reciprocal shaker as per the above procedure. After shaking, the aqueous phase was separated from the solid by centrifugation as per the above procedure. The $\mathrm{pH}$ of the supernatant was measured using a $\mathrm{pH}$ meter, and the concentration of silver ion in the supernatant was determined using ICP-AES to calculate $R$.

\subsubsection{Effect of Initial $\mathrm{Ag}^{+}$Solution Concentration}

The effect of initial $\mathrm{Ag}^{+}$solution concentration on the adsorption capacity of clinoptilolite was determined using solutions of concentrations ranging from 0.1 to $5 \mathrm{mM}$. First, $0.1 \mathrm{~g}$ zeolite sample was added to $20 \mathrm{~mL} \mathrm{Ag}^{+}$solution in a tube at room temperature, and the tube was shaken for $2 \mathrm{~h}$ as per the above procedure. After shaking, the aqueous phase was separated from the solid by centrifugation as per the above procedure, and the $\mathrm{Ag}^{+}$supernatant concentration was determined by ICP-AES to calculate $q_{\mathrm{e}}$ and $R$.

\subsubsection{Effect of Temperature on Adsorption Time}

To determine the adsorption time of $\mathrm{Ag}^{+}$from aqueous solution onto clinoptilolite, $1 \mathrm{~g}$ zeolite sample was added to $200 \mathrm{~mL}(1 \mathrm{mM}) \mathrm{AgNO}_{3}$ solution in a $500-\mathrm{mL}$ glass beaker, and the mixture was stirred using a magnetic stirrer at $20^{\circ} \mathrm{C}$. While stirring, $2-\mathrm{mL}$ aliquots were sampled from the solution at varying times, and the $\mathrm{Ag}^{+}$concentration in the filtrate was determined by ICP-AES to calculate the amount of $\mathrm{Ag}^{+}$adsorbed on the zeolite at a sampling time $t, q_{\mathrm{t}}$, using the difference between initial $\mathrm{Ag}^{+}$concentration 
and the $\mathrm{Ag}^{+}$concentration at sampling times. To study the effect of temperature on the adsorption time, the experiments were conducted at two additional temperatures, i.e., $30^{\circ} \mathrm{C}$ and $40^{\circ} \mathrm{C}$.

\section{Results and Discussion}

\subsection{Silver Adsorption}

Solution $\mathrm{pH}$ is an important factor that influences $\left(\mathrm{Ag}^{+}\right)$adsorption at solid-liquid interfaces. The $\mathrm{pH}$ dependence of $\mathrm{Ag}^{+}$adsorption onto zeolite is shown in Figure 1. Experiments were conducted using silver ion solutions at different $\mathrm{pH}$ values. As observed, $\mathrm{Ag}^{+}$adsorption uptake, $q_{\mathrm{e}}$, was low at low $\mathrm{pHs}$, then increased with increasing $\mathrm{pHs}$ before decreasing with further increased in $\mathrm{pH}(>4)$, and subsequently reached a plateau at $\mathrm{pH}>6.0$. The highest $q_{\mathrm{e}}$ was obtained at equilibrium $\mathrm{pH}$ of around 4 . These results agreed with the results of several investigations on $\mathrm{Ag}^{+}$removal [71]-[75]. These studies attributed the low adsorption capacity at $\mathrm{pH}<4$ to the competition between protons and $\mathrm{Ag}^{+}$for the exchange sites on the zeolite particle [76] [77]. With increasing $\mathrm{pHs}$, precipitation of $\mathrm{Ag}$ on the zeolite at higher $\mathrm{pH}$ values can occur, thereby decreasing the adsorption/ion exchange uptake to reach equilibrium $\mathrm{Ag}^{+}$concentration.

Figure 2 shows the change in the solution equilibrium $\mathrm{pH}$ as a function of solution initial $\mathrm{pH}$. The solution equilibrium $\mathrm{pH}$ increased when the initial $\mathrm{pH}$ was between 2 and 6. These results show that the zeolite has a negative surface charge at a $\mathrm{pH}$ of $\sim 2$ and that the lower uptake results from competition between the $\mathrm{Ag}^{+}$and $\mathrm{H}^{+}$ions for the adsorption/exchange sites. In the $\mathrm{pH}$ range of $2-6, \mathrm{Ag}^{+}$uptake is accompanied by an increase in solution $\mathrm{pH} . \mathrm{Ag}^{+}$uptake is believed to proceed via ion exchange and/or adsorption mechanism. However, this increase in $\mathrm{pH}$ suggests that the reaction likely proceeds via an ion exchange mechanism and exchangeable cations are released in the aqueous solution.

Figure 3 illustrates the effect of adsorbent dosage on the solution $\mathrm{pH}$ and silver

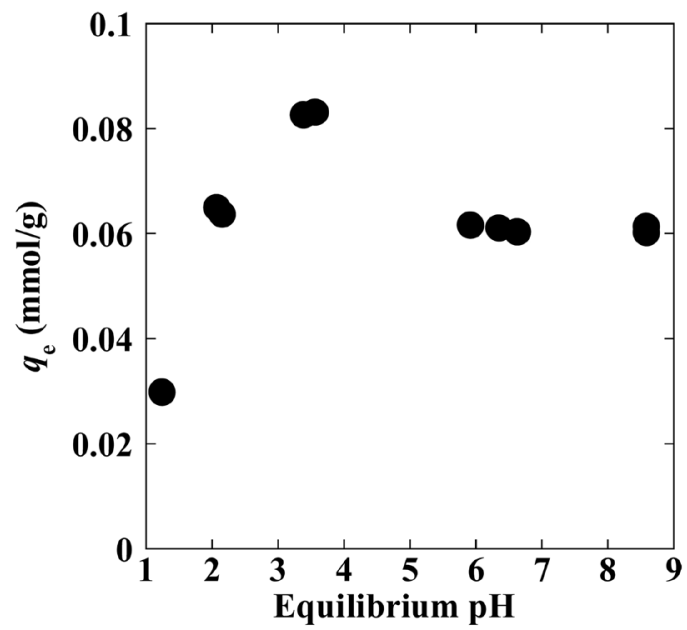

Figure 1. $\mathrm{pH}$ dependence of silver adsorption on natural clinoptilolite zeolite. 


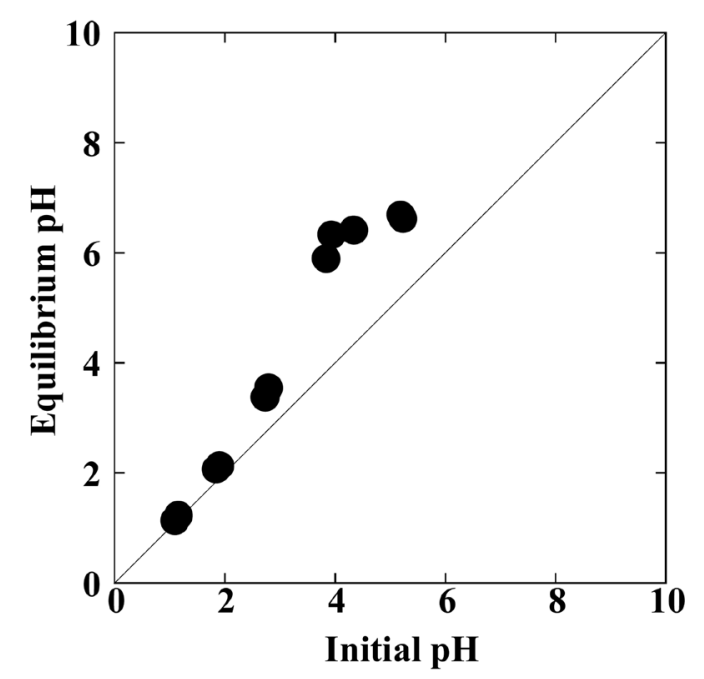

Figure 2. Variations in solution equilibrium $\mathrm{pH}$ as a function of solution initial $\mathrm{pH}$.

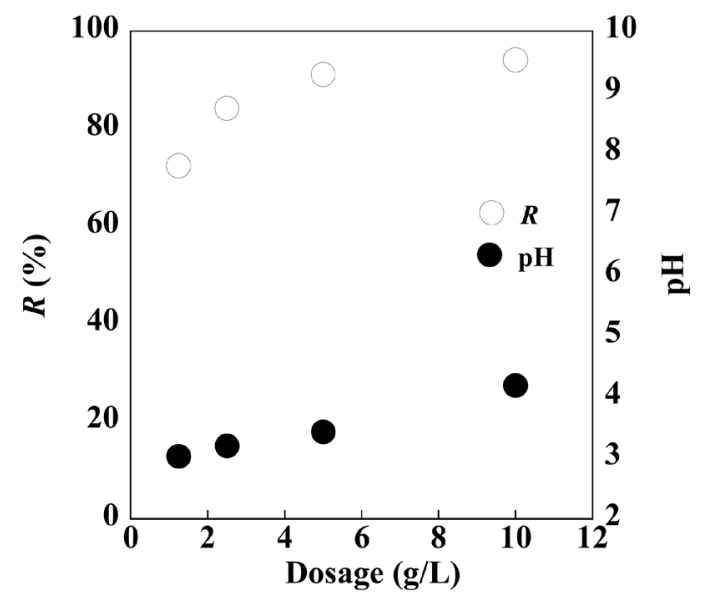

Figure 3. Effect of adsorbent dosage on solution $\mathrm{pH}$ and silver removal by clinoptilolite.

removal by clinoptilolite. With an increase in dosage, both the removal percentage and solution $\mathrm{pH}$ increased to approximately $95 \%$ and from 3 to 4 , respectively. This result indicates that adsorbent dosages greater than $5 \mathrm{~g} / \mathrm{L}$ are suitable to achieve efficient removal of silver from the solution.

Subsequently, the effect of varying the initial $\mathrm{Ag}^{+}$solution concentration (0.2 - 5 $\mathrm{mM}$ ) on the $\mathrm{Ag}^{+}$uptake and removal from the solution was examined, and the results are shown in Figure 4. With increasing initial $\mathrm{Ag}^{+}$solution concentrations, the adsorption capacity increased, whereas the $\mathrm{Ag}^{+}$removal percentage decreased. These results indicate that energetically less favorable sites become involved with increasing $\mathrm{Ag}^{+}$ concentrations in the aqueous solution.

Figure 6 shows the adsorption profiles of $\mathrm{Ag}^{+}$onto the zeolite sample at varying reaction temperatures of $20^{\circ} \mathrm{C}, 30^{\circ} \mathrm{C}$, and $40^{\circ} \mathrm{C}$. The slopes of the lines joining the data 
points in the figure reflect the adsorption rates. As observed from Figure 5, with increasing solution temperatures, the uptake of $\mathrm{Ag}^{+}$decreased. However, the adsorption time was faster at the higher solution temperatures. Specifically, at $30^{\circ} \mathrm{C}$ and $40^{\circ} \mathrm{C}$, the amount of adsorbed $\mathrm{Ag}^{+}$increased rapidly before reaching an equilibrium value after 20 min. In contrast, at a solution temperature of $20^{\circ} \mathrm{C}$, an equilibrium value was attained after $45 \mathrm{~min}$. In a previous study, several adsorbents were examined toward the removal of $\mathrm{Ag}^{+}$; an equilibrium adsorption time of $5 \mathrm{~h}$ was reported [78]. Short adsorption times are preferred owing to the lower energy consumption requirements. Thus, comparison between the adsorbents studied in the literature [78] and the present zeolite reveals that the latter is more efficient owing to the shorter adsorption time.

\subsection{Adsorption Isotherm and Kinetics Studies}

Figure 6 shows the silver adsorption isotherm of the zeolite sample. With increasing

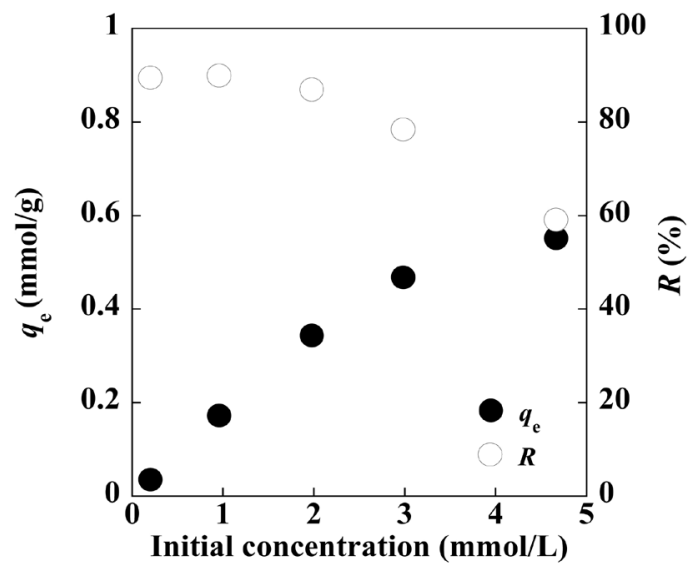

Figure 4. Variations in the silver ion uptake and silver removal as a function of initial silver ion solution concentration.

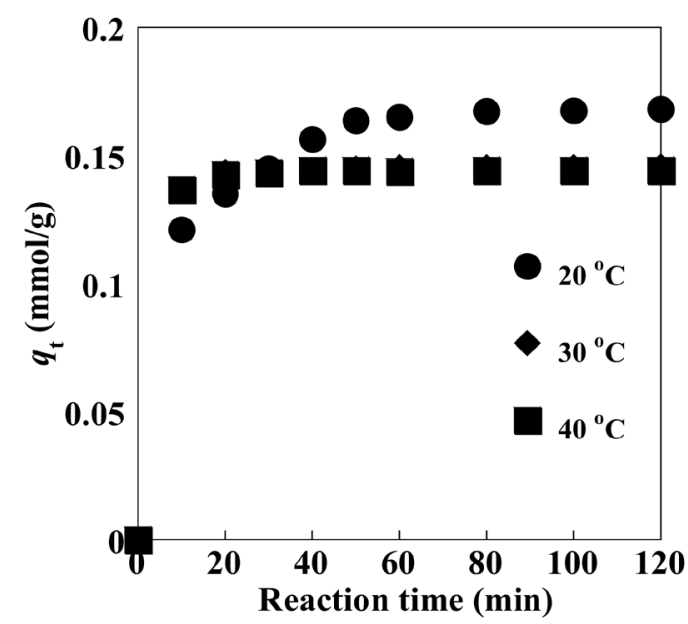

Figure 5. Silver ion adsorption on clinoptilolite at $20^{\circ} \mathrm{C}, 30^{\circ} \mathrm{C}$, and $40^{\circ} \mathrm{C}$ as a function of reaction time. 


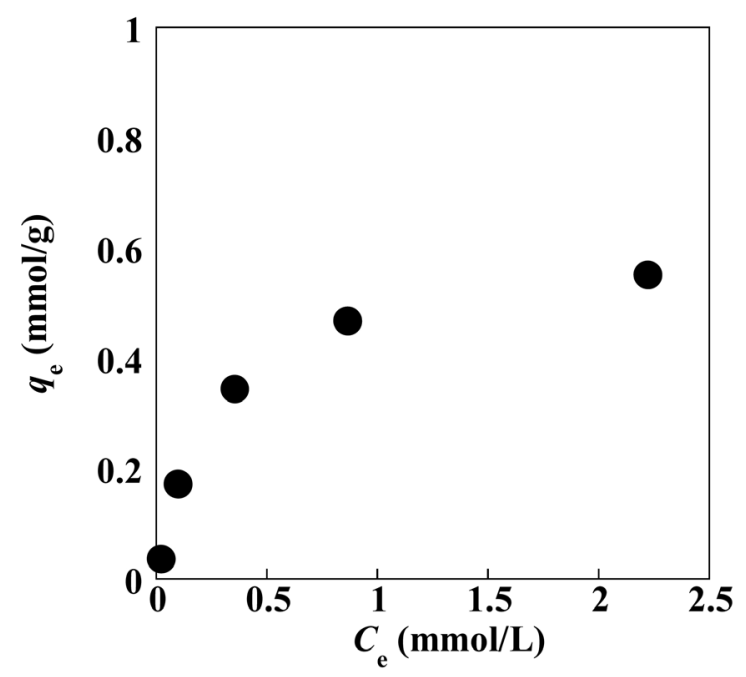

Figure 6. Silver ion adsorption capacity of clinoptilolite.

equilibrium concentrations, the silver ion uptake increased to approximately 0.6 $\mathrm{mmol} / \mathrm{g}$ before reaching a plateau.

The equilibrium distribution of $\mathrm{Ag}^{+}$between the zeolite and solution is important in determining the maximum sorption capacity. Several isotherm models are available to describe the equilibrium sorption distribution. In the present study, two models, i.e., Langmuir and Freundlich, were used to fit the experimental data.

The linear form of the Langmuir model can be expressed as follows:

$$
C_{\mathrm{e}} / q_{\mathrm{e}}=1 /\left(Q_{\max } K_{\mathrm{L}}\right)+C_{\mathrm{e}} / q_{\max },
$$

where $Q_{\max }(\mathrm{mmol} / \mathrm{g})$ and $K_{\mathrm{L}}(\mathrm{L} / \mathrm{mmol})$ are Langmuir constants related to the maximum adsorption capacity corresponding to complete coverage of available adsorption sites and a measure of adsorption energy (equilibrium adsorption constant), respectively. These constants can be respectively determined from the slope and intercept of the linear plot of $C_{\mathrm{e}} / q_{\mathrm{e}}$ vs. $C_{\mathrm{e}}$ so that $Q_{\max }=1 /$ slope and $K_{\mathrm{L}}=$ slope/intercept.

The linear form of the Freundlich model can be expressed as follows:

$$
\ln \left(q_{\mathrm{e}}\right)=\ln \left(K_{\mathrm{F}}\right)+\ln \left(C_{\mathrm{e}}\right) / n,
$$

where $K_{\mathrm{F}}$ and $n$ are Freundlich constants determined from the slope and intercept of the plot of $\ln \left(q_{\mathrm{e}}\right)$ vs. $\ln \left(C_{\mathrm{e}}\right)$.

The Langmuir and Freundlich isotherm models were applied to the experimental data presented in Figure 5, and the associated parameters calculated from the fitted data are shown in Table 2. As observed from Table 2, the Langmuir model fitted the data better than the Freundlich model owing to the higher correlation regression coefficient $R^{2}$ (measure of the goodness-of-fit) of the data fitted with the Langmuir model. As discussed in a previous study [79], the uptake of various metals by natural zeolite can be attributed to different ion-exchange mechanisms and adsorption processes. $Q_{\max }$, as calculated from the Langmuir isotherm model, was $0.64 \mathrm{mmol} / \mathrm{g}$. The $Q_{\max }$ value obtained here is comparable with those reported in the literature. For instance, 
Table 2. Langmuir- and Freundlich-fitted adsorption parameters and associated correlation regression coefficients.

\begin{tabular}{cccccc}
\hline \multicolumn{3}{c}{ Langmuir model } & \multicolumn{3}{c}{ Freundlich model } \\
\hline$Q_{\max }(\mathrm{mmol} / \mathrm{g})$ & $K_{\mathrm{L}}(\mathrm{L} / \mathrm{mmol})$ & $R^{2}$ & $n$ & $K_{\mathrm{F}}$ & $R^{2}$ \\
0.64 & 3.7 & 0.995 & 1.64 & 0.55 & 0.898 \\
\hline
\end{tabular}

the adsorption of $\mathrm{Ag}^{+}$onto $\mathrm{H}-\mathrm{Na}-\mathrm{ZDM}-5$ zeolite [80], mordenite [81], different types of chitosan [82], and coal [83] generated maximum adsorption capacities of $0.57,0.04$ $0.21,0.4$, and $0.017 \mathrm{mmol} / \mathrm{g}$ adsorbent, respectively.

The kinetics adsorption data obtained from Figure 5 were analyzed using different kinetics models, i.e., the Lagergren pseudo-first-order [84]-[86] and pseudo-secondorder [87]-[102] models. The Lagergren pseudo-first-order model can be described as follows:

$$
\ln \left(q_{\mathrm{e}}-q_{\mathrm{t}}\right)=\ln \left(q_{\mathrm{e}}\right)-k_{1} t
$$

where $q_{t}\left(\mathrm{mmol}\right.$ of $\mathrm{Ag}^{+} / \mathrm{g}$ zeolite $)$ is the amount of $\mathrm{Ag}^{+}$adsorbed on the zeolite at time $t$ and $k_{1}\left(\mathrm{~min}^{-1}\right)$ is the adsorption rate constant. Parameters $k_{1}$ and $\ln \left(q_{\mathrm{e}}\right)$ can be respectively deduced from the slope and intercept of the linear plot of $\ln \left(q_{\mathrm{e}}-q_{\mathrm{t}}\right)$ vs. $t$.

The linear form of the pseudo-second-order model can be expressed as follows:

$$
t / q_{\mathrm{t}}=1 /\left(q_{\mathrm{e}}^{2} k_{2}\right)+t / q_{\mathrm{e}},
$$

where $k_{2}(\mathrm{~g} / \mathrm{mmol} \mathrm{min})$ is the adsorption rate constant, and $k_{2}$ and $q_{\mathrm{e}}$ can respectively be determined from the intercept and slope of the plot of $t / q_{t}$ vs. $t$ so that $q_{\mathrm{e}}=1 /$ slope and $k_{2}=$ slope $^{2} /$ intercept. The rate constants of the pseudo-first-order, $k_{1}$, and pseudo-second-order, $k_{2}$, reaction for $\mathrm{Ag}^{+}$adsorption were determined from Figure 6 . The values of $k_{1}, k_{2}, R^{2}$, and $q_{\mathrm{e}}$ (i.e., $q_{\mathrm{e}, 1}$ and $q_{\mathrm{e}, 2}$ ) are presented in Table 3. Comparison of the $R^{2}$ values reveals that the adsorption process follows the pseudo-second-order model better than the pseudo-first-order model.

As can be deduced from Table 3, $q_{e, 2}$ and $k_{2}$ were dependent on the reaction temperature. To gain insights into the thermodynamic nature of the adsorption process, several thermodynamic parameters were calculated. The Gibbs free energy change, $\Delta G^{0}$, was negative, as calculated from the following equation:

$$
\Delta G^{0}=R T \ln K_{\mathrm{c}},
$$

where $K_{\mathrm{c}}$ is the adsorption equilibrium constant, $R(8.314 \mathrm{~J} /(\mathrm{mol} \cdot \mathrm{K}))$ is the gas constant, and $T(\mathrm{~K})$ is the absolute temperature. $K_{\mathrm{c}}$ can be calculated as follows:

$$
K_{\mathrm{c}}=F_{\mathrm{e}} /\left(1-F_{\mathrm{e}}\right) \text {, }
$$

where $F_{\mathrm{e}}$ is the fraction of $\mathrm{Ag}^{+}$adsorbed at equilibrium and is obtained by the expression:

$$
F_{\mathrm{e}}=\left(C_{0}-C_{\mathrm{e}}\right) / C_{\mathrm{e}} .
$$

Parameters $C_{0}$ and $C_{\mathrm{e}}$ are the initial and equilibrium concentrations of $\mathrm{Ag}^{+}$in solution $(\mathrm{mmol} / \mathrm{L})$. 
Table 3. Adsorption kinetics parameters and associated correlation regression coefficients.

\begin{tabular}{ccccccc}
\hline \multirow{2}{*}{$\begin{array}{c}\text { Reaction } \\
\text { temperature } \\
\left({ }^{\circ} \mathrm{C}\right)\end{array}$} & \multicolumn{2}{c}{ Pseudo-first-order kinetics model } & \multicolumn{2}{c}{ Pseudo-second-order kinetics model } \\
\cline { 2 - 6 } & $\begin{array}{c}q_{\mathrm{e}, 1} \\
(\mathrm{mmol} / \mathrm{g})\end{array}$ & $\begin{array}{c}k_{1}\left(\times 10^{-2}\right) \\
(1 / \mathrm{min})\end{array}$ & $R^{2}$ & $\begin{array}{c}q_{\mathrm{e}, 2} \\
(\mathrm{mmol} / \mathrm{g})\end{array}$ & $\begin{array}{c}k_{2} \\
(\mathrm{~g} /(\mathrm{mmol} \cdot \mathrm{min}))\end{array}$ & $R^{2}$ \\
\hline 20 & 0.047 & 1.76 & 0.824 & 0.18 & 1.1 & 0.999 \\
30 & 0.005 & 1.96 & 0.782 & 0.15 & 13.0 & 1.000 \\
40 & 0.003 & 1.88 & 0.495 & 0.14 & 23.0 & 1.000 \\
\hline
\end{tabular}

The $K_{\mathrm{c}}$ values associated with the adsorption of $\mathrm{Ag}^{+}$on the zeolite at different temperatures were calculated using Equations (8) and (9), and the results are presented in Table 4. The $K_{\mathrm{c}}$ value obtained at $20^{\circ} \mathrm{C}$ was higher than those at $30^{\circ} \mathrm{C}$ and $40^{\circ} \mathrm{C}$. This result implies the strengthening of the adsorbate-adsorbent interactions at the lower temperature of $20^{\circ} \mathrm{C}$. Additionally, the obtained negative $\Delta G^{\circ}$ values confirmed the feasibility and spontaneous nature of the adsorption process.

The Gibbs free energy can also be represented as follows:

$$
\Delta G^{0}=\Delta H^{0}-T \Delta S^{0} .
$$

The enthalpy change $\left(\Delta H^{\dagger}\right)$ and entropy change $\left(\Delta S^{0}\right)$ change, which were calculated from the intercept and slope of the plot of $\Delta G^{0}$ versus $T$, are presented in Table 4 . The negative $\Delta H^{\dagger}$ value obtained confirmed the exothermic nature of the adsorption process. The negative $\Delta S^{0}$ value indicated the decrease in the degree of randomness at the solid-solution interface with some structural changes in the adsorbate and adsorbent.

The activation energy related to the silver adsorption on clinoptilolite was calculated by the Arrhenius equation:

$$
k_{2}=A \exp (-\Delta E / R T),
$$

where $\Delta E(\mathrm{~kJ} / \mathrm{mol})$ is the activation energy, $A$ is the frequency factor, $T(\mathrm{~K})$ is the absolute temperature, and $R$ is the gas constant. From the plot of $\ln \left(k_{2}\right)$ vs. $1 / T$ (Figure 7), the activation energy for the adsorption of silver was found to be $116 \mathrm{~kJ} / \mathrm{mol}$.

\section{Conclusion}

In the present study, the interaction between $\mathrm{Ag}^{+}$and clinoptilolite zeolite was investigated. The results indicated that several factors, i.e., $\mathrm{pH}$, adsorbent dosage, adsorption time, initial $\mathrm{Ag}^{+}$solution concentration, and temperature, influenced the adsorption process. Of particular interest, the amount of $\mathrm{Ag}^{+}$adsorbed on clinoptilolite was highest at around $\mathrm{pH} 4$, and the $\mathrm{Ag}^{+}$uptake increased with decreasing solution temperatures. The experimental data were fitted with the Langmuir and Freundlich adsorption isotherm models. The results revealed that the process was best described by the Langmuir model. The maximum adsorption capacity of the zeolite, as calculated from the Langmuir model, was $0.64 \mathrm{mmol} / \mathrm{g}$. The $\mathrm{Ag}^{+}$adsorption kinetics from aqueous solution followed the pseudo-second-order model. The thermodynamic studies revealed that $\mathrm{Ag}^{+}$ 
Table 4. Thermodynamics parameters of silver ion adsorption on clinoptilolite.

\begin{tabular}{ccccc}
\hline Reaction temperature $(\mathrm{K})$ & $K_{\mathrm{c}}$ & $\Delta G^{0}(\mathrm{~kJ} / \mathrm{mol})$ & $\Delta H^{0}(\mathrm{~kJ} / \mathrm{mol})$ & $\Delta S^{0}(\mathrm{~J} /(\mathrm{mol} \cdot \mathrm{K}))$ \\
\hline $293\left(20^{\circ} \mathrm{C}\right)$ & 3.95 & -3.35 & & \\
$303\left(30^{\circ} \mathrm{C}\right)$ & 2.72 & -2.52 & -12.7 & -32.5 \\
$313\left(40^{\circ} \mathrm{C}\right)$ & 2.81 & -2.70 & & \\
\hline
\end{tabular}

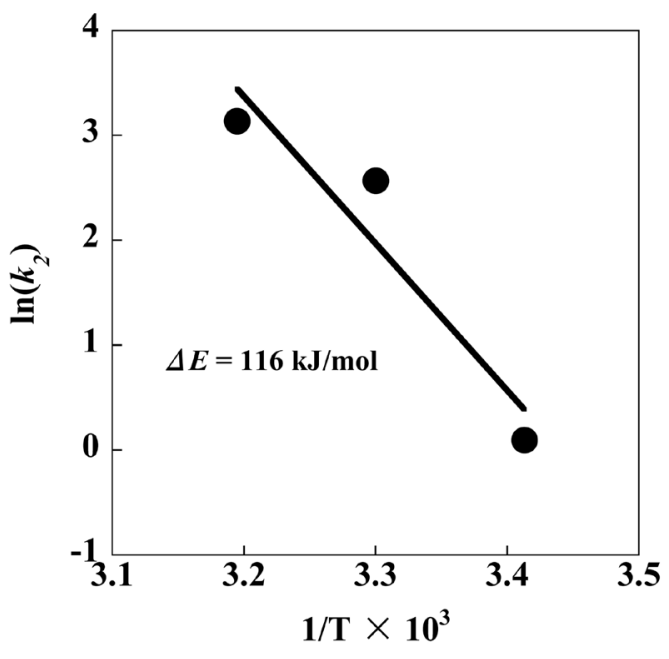

Figure 7. Arrhenius plot of silver adsorption on clinoptilolite.

adsorption on the zeolite was an exothermic and spontaneous process. In summary, the current findings demonstrate the potential of Japanese clinoptilolite as a suitable and efficient material for the removal of $\mathrm{Ag}^{+}$from aqueous solution.

\section{References}

[1] Abollino, O., Aceto, M., Sarzanini, C. and Mentasti, E. (2000) The Retention of Metal Species by Different Solid Sorbents: Mechanism for Heavy Metal Speciation by Sequential Three Column Uptake. Analytica Chimica Acta, 411, 223-237. http://dx.doi.org/10.1016/S0003-2670(00)00742-X

[2] Huang, C.P., Tsong, M.W. and Hsieh, Y.S. (1985) AIChE Symposium Series Heavy Metal Separation Processes. In: Peters, K. and Bhattaacharya, D., Eds., American Institute of Chemical Engineers, New York.

[3] Alloway, B.J. and Ayres, D.C. (1993) Chemical Principles of Environmental Pollution. Blackie Academic \& Professional, London. http://dx.doi.org/10.1007/978-94-011-2148-4

[4] Abbasi, S.A., Abbasi, N. and Soni, R. (1998) Heavy Metals in the Environment. Mittal, New Delhi.

[5] Al-Haj Ali, A. and El-Bishtawi, R. (1997) Removal of Lead and Nickel Ions Using Zeolite Tuff. Journal of Chemical Technology and Biotechnology, 69, 27-34. http://dx.doi.org/10.1002/(SICI)1097-4660(199705)69:1<27::AID-JCTB682>3.0.CO;2-J

[6] Sanchez, A.G., Ayuso, E.A. and Blass, O.J. (1999) Sorption of Heavy Metals from Industrial Waste Water by Low-Cost Mineral Silicates. Clay Minerals, 34, 469-477. http://dx.doi.org/10.1180/000985599546370 
[7] Grant, D.C., Skriba, M.C. and Saha, A.K. (1987) Removal of Radioactive Contaminants from West Valley Waste Streams Using Natural Zeolites. Environmental Progress, 6, 104109. http://dx.doi.org/10.1002/ep.670060212

[8] Virta, R. (2001) USGS Minerals Information, US Geological Survey Min. Commodity Summary 2000, January 2001.

[9] Ouki, S. and Kavannagh, M. (1997) Performance of Natural Zeolites for the Treatment of Mixed Metal-Contaminated Effluents. Waste Management and Research, 15, 383-394. http://dx.doi.org/10.1177/0734242X9701500406

[10] Sheppard, R.A. (1976) Zeolites in Sedimentary Deposits of the Northwestern United States-Potential Industrial Minerals. Montana Bureau of Mines and Geology, 74, 69.

[11] Bish, D.L. and Ming, D.W. (2001) Natural Zeolite: Occurrence, Properties, Applications. Mineralogical Society of America, Washington.

[12] Breck, D.W. (1974) Zeolite Molecular Sieves. Wiley, New York.

[13] Mondale, K.D., Carland, R.M. and Aplan, F.F. (1995) The Comparative Ion Exchange Capacities of Natural Sedimentary and Synthetic Zeolites. Minerals Engineering, 8, 535-548. http://dx.doi.org/10.1016/0892-6875(95)00015-I

[14] Carland, R.M. and Aplan, F.F. (1995) Use of Natural Sedimentary Zeolites for Metal Ion Recovery from Hydrometallurgical Solutions and for the Environmental Remediation of Acid Mine Drainage. Proceedings of the 19th International Mineral Processing Congress, San Francisco, 22-27 October 1995, 210.

[15] Joshi, M.S. and Mohan, R.P. (1983) Cation Sieve Properties of Natural Heulandite. Journal of Colloid and Interface Science, 95, 131-134. http://dx.doi.org/10.1016/0021-9797(83)90080-2

[16] Blanchard, G., Maunaye, M. and Martin, G. (1984) Removal of Heavy Metals from Waters by Means of Natural Zeolites. Water Research, 18, 1501-1507. http://dx.doi.org/10.1016/0043-1354(84)90124-6

[17] Zamzow, M.J., Eichbaum, B.R., Sandgren, K.R. and Shanks, D.E. (1990) Removal of Heavy Metals and Other Cations from Wastewater Using Zeolites. Separation Science and Technology, 25, 1555-1569. http://dx.doi.org/10.1080/01496399008050409

[18] Environmental Protection Agency (EPA) (1977) Manual of Treatment Techniques for Meeting in Interim Primary Drinking Water Regulation. EPA, Cincinnati.

[19] Kapoor, A. and Viraraghavan, T. (1995) Fungal Biosorption-An Alternative Treatment Option for Heavy Metal Bearing Wastewaters: A Review. Bioresource Technology, 53, 195-206.

[20] Modak, J.M. and Natarajan, K.A. (1995) Biosorption of Metals Using Nonliving BiomassA Review. Minerals and Metallurgical Processing, 12, 189-195.

[21] Volesky, B. (1999) Biohydrometallurgy and the Environment toward the Mining of the 21st Century, Part B. In: Amils, R. and Ballester, A., Eds., Proceedings of the International Biohydrometallurgy Symposium, Elsevier, Amsterdam.

[22] Hashemian, S., Hosseini, S.H., Salehifar, H. and Salari, K. (2013) Adsorption of Fe(III) from Aqueous Solution by Linde Type-A Zeolite. American Journal of Analytical Chemistry, 4, 123-126. http://dx.doi.org/10.4236/ajac.2013.47a017

[23] Chmielewska, E. (1999) Environmental Zeolites and Aqueous Media: Examples of Practical Solutions. Bentham Books, Beijing.

[24] Inoue, Y., Hoshino, M., Takahashi, H., Naguchi, T., Murata, T., Kanzaki, Y., Hamashima, H. and Sasatsu, M. (2002) Bactericidal Activity of Ag-Zeolite Mediated by Reactive Oxygen 
Species under Aerated Conditions. Journal of Inorganic Biochemistry, 92, 37-42. http://dx.doi.org/10.1016/S0162-0134(02)00489-0

[25] Kawahara, K., Tsuruda, K., Morishita, M. and Uchida, M. (2000) Antibacterial Effect of Silver-Zeolite on Oral Bacteria under Anaerobic Conditions. Dental Materials, 16, 452-455. http://dx.doi.org/10.1016/S0109-5641(00)00050-6

[26] Alcamo, I.E. (2004) Microbes and Society: An Introduction to Microbiology. Jones and Bartlett Publishers, Sudbury.

[27] Landsdown, A.B. (2002) Silver I: Its Antibacterial Properties and Mechanism of Action. Journal of Wound Care, 11, 125-130. http://dx.doi.org/10.12968/jowc.2002.11.4.26389

[28] Grujer, N. and Von-Guten, U. (2003) A Stochastic Model of an Ozonation Reactor. Water Research, 37, 1667-1677. http://dx.doi.org/10.1016/S0043-1354(02)00456-6

[29] Joyakumar, R., Lee, Y.S., Rajkumar, M. and Najundan, S. (2004) Synthesis, Characterization and Antibacterial Activity of Metal-Containing Polyurethanes. Journal of Applied Polymer Science, 91, 288-295. http://dx.doi.org/10.1002/app.13222

[30] Sondi, I. and Salopek-Sondi, B. (2004) Silver Nanoparticles as Antimicrobial Agent: A Case Study on E. coli as a Model for Gram-Negative Bacteria. Journal of Colloid and Interface Science, 275, 177-182. http://dx.doi.org/10.1016/j.jcis.2004.02.012

[31] Top, A. and Ülkü, S. (2004) Silver, Zinc and Copper Exchange in a Na-Clinoptilolite and Resulting Effect on Antibacterial Activity. Applied Clay Science, 27, 13-19. http://dx.doi.org/10.1016/j.clay.2003.12.002

[32] Koivunen, J. and Heinonen-Tanski, H. (2005) Inactivation of Enteric Microorganisms with Chemical Disinfectants, UV Irradiation and Combined Chemical/UV Treatments. Water Research, 39, 1519-1526. http://dx.doi.org/10.1016/j.watres.2005.01.021

[33] Son, H., Cho, M., Kim, J., Oh, B., Chung, H. and Yoon, J. (2005) Enhanced Disinfection Efficiency of Mechanically Mixed Oxidants with Free Chlorine. Water Research, 39, 721-727. http://dx.doi.org/10.1016/j.watres.2004.10.018

[34] Jiang, S., Wang, L., Yu, H., Chen, Y. and Shi, Q. (2006) Study on Antibacterial Behavior of Insoluble Quaternary Ammonium. Journal of Applied Polymer Science, 99, 2389-2394. http://dx.doi.org/10.1002/app.22810

[35] Song, H.Y., Ko, K.K., Oh, I.H. and Lee, B.T. (2006) Fabrication of Silver Nanoparticles and their Antimicrobial Mechanisms. European Cells and Materials, 11, 58.

[36] Silvestry-Rodriguez, N., Sicairos-Ruelas, E.E., Gerba, C.P. and Bright, K.R. (2007) Silver as a Disinfectant. In: Reviews of Environmental Contamination and Toxicology, Reviews of Environmental Contamination and Toxicology Vol. 191, Springer, New York, 23-45. http://dx.doi.org/10.1007/978-0-387-69163-3_2

[37] Chen, X. and Schluesener, H.J. (2008) Nanosilver: A Nanoproduct in Medical Application. Toxicology Letters, 176, 1-12. http://dx.doi.org/10.1016/j.toxlet.2007.10.004

[38] Russell, A.D. and Hugo, W.B. (1994) Antimicrobial Activity and Action of Silver. Progress in Medicinal Chemistry, 31, 351-370. http://dx.doi.org/10.1016/S0079-6468(08)70024-9

[39] Rai, M., Yadav, A. and Gade, A. (2009) Silver Nanoparticles as a New Generation of Antimicrobials. Biotechnology Advances, 27, 76-83. http://dx.doi.org/10.1016/j.biotechadv.2008.09.002

[40] Feng, Q.L., Wu, J., Chen, G.Q., Cui, F.Z., Kim, T.N. and Kim, J.O. (2000) A Mechanistic Study of the Antibacterial Effect of Silver Ions on Escherichia coli and Staphylococcus aureus. Journal of Biomedical Materials Research Part A, 52, 662-668. http://dx.doi.org/10.1002/1097-4636(20001215)52:4<662::AID-JBM10>3.0.CO;2-3 
[41] Kawashita, M., Tsuneyama, S., Miyaji, F., Kokubo, T., Kozuka, H. and Yamamoto, K. (2000) Antibacterial Silver-Containing Silica Glass Prepared by Sol-Gel Method. Biomaterials, 21, 393-398. http://dx.doi.org/10.1016/S0142-9612(99)00201-X

[42] Lanje, A.S., Sharma, S.J. and Pode, R.B. (2010) Synthesis of Silver Nanoparticles: A Safer Alternative to Conventional Antimicrobial and Antibacterial Agents. Journal of Chemical and Pharmaceutical Research, 2, 478-483.

[43] Sotiriou, G.A. and Pratsinis, S.E. (2010) Antibacterial Activity of Nanosilver Ions and Particles. Environmental Science and Technology, 44, 5649-5654. http://dx.doi.org/10.1021/es101072s

[44] Guggenbichler, J.P., Boswald, M., Lugauer, S. and Krall, T. (1999) A New Technology of Microdispersed Silver in Polyurethane Induces Antimicrobial Activity in Central Venous Catheters. Infection, 27, S16-S23. http://dx.doi.org/10.1007/bf02561612

[45] Schierholz, J.M., Beuth, J., Pulverer, G. and Konig, D.P. (1999) Silver-Containing Polymers. Antimicrobial Agents and Chemotherapy, 43, 2819-2821.

[46] Furno, F., Morley, K.S., Wong, B., Sharp, B.L., Arnold, P.L., Howdle, S.M., Bayston, R., Brown, P.D., Winship, P.D. and Reid, H.J. (2004) Silver Nanoparticles and Polymeric Medical Devices: A New Approach to Prevention of Infection? Journal of Antimicrobial Chemotherapy, 54, 1019-1024. http://dx.doi.org/10.1093/jac/dkh478

[47] Incoronato, A.L., Buonocore, G.G., Conte, A., Lavorgna, M., Nobile, M. and Del, M.A. (2010) Active Systems Based on Silver-Montmorillonite Nanoparticles Embedded into BioBased Polymer Matrices for Packaging Application. Journal of Food Protection, 73, 22562262.

[48] Bellantone, M., Williams, H.D. and Hench, L.L. (2002) Broad-Spectrum Bactericidal Activity of $\mathrm{Ag}_{2} \mathrm{O}$-Doped Bioactive Glass. Antimicrobial Agents and Chemotherapy, 46, 1940 1945. http://dx.doi.org/10.1128/AAC.46.6.1940-1945.2002

[49] Keleher, J., Jennifer, B., Heldt, N., Johnson, L. and Li, Y. (2002) Photo-Catalytic Preparation of Silver-Coated $\mathrm{TiO}_{2}$ Particles for Antibacterial Applications. World Journal of Microbiology and Biotechnology, 18, 133-139. http://dx.doi.org/10.1023/A:1014455310342

[50] Toshikazu, T. (1999) Antimicrobial Agent Composed of Silica-Gel with Silver Complex. Inorganic Materials, 6, 505-511.

[51] Jeon, H.J., Yi, S.C. and Oh, S.G. (2003) Preparation and Antibacterial Effects of Ag-SiO Thin Films by Sol-Gel Method. Biomaterials, 24, 4921-4928.

http://dx.doi.org/10.1016/S0142-9612(03)00415-0

[52] Catauro, M., Raucci, M., De Gaetano, F. and Marotta, A. (2004) Antibacterial and Bioactive Silver-Containing $\mathrm{Na}_{2} \mathrm{O} \cdot \mathrm{CaO} \cdot 2 \mathrm{SiO}_{2}$ Glass Prepared by Sol-Gel Method. Journal of Materials Science: Materials in Medicine, 15, 831-837. http://dx.doi.org/10.1023/B:JMSM.0000032825.51052.00

[53] Kawashita, M., Toda, S., Kim, H.M., Kokubo, T. and Matsuda, N. (2003) Preparation of Antibacterial Silver-Doped Silica Glass Microspheres. Journal of Biomedical Materials Research Part A, 66A, 266-274. http://dx.doi.org/10.1002/jbm.a.10547

[54] Ozdemir, G., Limoncu, M.H. and Yapar, S. (2010) The Antibacterial Effect of Heavy Metal and Cetylpridinium-Exchanged Montmorillonites. Applied Clay Science, 48, 319-323. http://dx.doi.org/10.1016/j.clay.2010.01.001

[55] Magana, S.M., Quintana, P., Aguilar, D.H., Toledo, J.A., Angeles-Chavez, C., Cortes, M.A., Leon, L., Freile-Pelerin, Y., Lopez, T. and Torres-Sanchez, R.M. (2008) Antibacterial Activity of Montmorillonites Modified with Silver. Journal of Molecular Catalysis A: Chemical, 281, 192-199. http://dx.doi.org/10.1016/j.molcata.2007.10.024 
[56] Hagiwara, Z., Ishino, H., Nohara, S., Tagawa, K. and Yamanaka, K. (1990) Zeolite Particles Retaining Silver Ions Having Antibacterial Properties. US Patent No. 4911898.

[57] Inoue, Y. and Kanzaki, Y. (1997) The Mechanism of Antibacterial Activity of Silver-Loaded Zeolite. Journal of Inorganic Biochemistry, 67, 377. http://dx.doi.org/10.1016/S0162-0134(97)80243-7

[58] Kirov, G.N. and Terziiski, G. (1997) Natural Zeolites Sofia'95. In: Kirov, G., Filizova, L. and Petrov, O., Eds., PENSOFT Publishers, Sofia-Moscow, 133-141.

[59] Galeano, B., Korff, E. and Nicholson, W.L. (2003) Inactivation of Vegetable Cells, but Not Spores, of Bacillus anthracis, B. cereus, and B. subtilis on Stainless Steel Surfaces Coated with an Antimicrobial Silver- and Zinc-Containing Zeolite Formulation. Applied and Environmental Microbiology, 69, 4329-4331. http://dx.doi.org/10.1128/AEM.69.7.4329-4331.2003

[60] Matsumura, Y., Yoshikata, K., Kunisaki, S. and Truchido, T. (2003) Mode of Bactericidal Action of Silver Zeolite and Its Comparison with That of Silver Nitrate. Applied and Environmental Microbiology, 69, 4278-4281. http://dx.doi.org/10.1128/AEM.69.7.4278-4281.2003

[61] Zhang, Y., Zhong, S., Zhang, M. and Lin, Y. (2009) Antibacterial Activity of Silver-Loaded Zeolite A Prepared by a Fast Microwave-Loading Method. Journal of Materials Science, 44, 457-462. http://dx.doi.org/10.1007/s10853-008-3129-5

[62] Kwakye-Awuah, B., Williams, C., Kenward, M.A. and Radecka, I. (2008) Antimicrobial Action and Efficiency of Silver-Loaded Zeolite X. Journal of Applied Microbiology, 104, 15161524. http://dx.doi.org/10.1111/j.1365-2672.2007.03673.x

[63] Lv, L., Luo, Y., Ng, W.J. and Zhao, X.S. (2009) Bactericidal Activity of Silver Nanoparticles Supported on Microporous Titanosilicate ETS-10. Microporous and Mesoporous Materials, 120, 304-309. http://dx.doi.org/10.1016/j.micromeso.2008.11.028

[64] Rivera-Garza, M., Olguín, M.T., García-Sosa, I., Alcántara, D. and Rodríguez-Fuentes, G. (2000) Silver Supported on Natural Mexican Zeolite as an Antibacterial Material. Microporous and Mesoporous Materials, 39, 431-444. http://dx.doi.org/10.1016/S1387-1811(00)00217-1

[65] Milan, Z., de Las Pozas, C., Cruz, M., Borja, R., Sanchez, E., Angonavan, K., Espinosa, Y. and Luna, B. (2001) The Removal of Bacteria by Modified Natural Zeolites. Journal of Environmental Science and Health, Part A, 36, 1073-1087. http://dx.doi.org/10.1081/ESE-100104132

[66] Concepción-Rosabal, B., Bogdanchikova, N., De la Rosa, I., Olguin, M.T., Alcantara, D. and Rodriguez-Fuentes, G. (2006) Properties and Utilization of Natural Zeolites. 7 th International Conference on the Occurrence, New Mexico, 16-21 July 2006, 88-89.

[67] Concepción-Rosabal, B., Rodríguez-Fuentes, G., Bogdanchikova, N., Bosch, P., Avalos, M. and Lara, V.H. (2005) Comparative Study of Natural and Synthetic Clinoptilolites Containing Silver in Different States. Microporous and Mesoporous Materials, 86, 249-255. http://dx.doi.org/10.1016/j.micromeso.2005.07.027

[68] De la Rosa-Gómez, I., Olguín, M.T. and Alcántara, D. (2008) Antibacterial Behavior of Silver-Modified Clinoptilolite-Heulandite Rich Tuff on Coliform Microorganisms from Wastewater in a Column System. Journal of Environmental Management, 88, 853-863. http://dx.doi.org/10.1016/j.jenvman.2007.04.005

[69] De la Rosa-Gomez, I., Olguin, M.T. and Alcántara, D. (2010) Silver-Modified Mexican Clinoptilolite-Rich Tuffs with Various Particle Sizes as Antimicrobial Agents against Escherichia coli. Journal of the Mexican Chemical Society, 54, 139-142. 
[70] Development of New Utilization of Materials (1994) Natural Zeolite and Its Utilization. No. 111 Committee, Japan Society for the Promotion of Science, Tokyo.

[71] Ouki, S.K. and Kavannagh, M. (1999) Treatment of Metals-Contaminated Wastewaters by Use of Natural Zeolites. Water Science and Technology, 39, 115-122. http://dx.doi.org/10.1016/S0273-1223(99)00260-7

[72] Doula, M. and Ioannou, A. (2003) The Effect of Electrolyte Anion on Cu Adsorption-Desorption by Clinoptilolite. Microporous and Mesoporous Materials, 58, 115-130. http://dx.doi.org/10.1016/S1387-1811(02)00610-8

[73] Cabrera, C. and Gabaadon, C. (2005) Sorption Characteristics of Heavy Metal Ions by a Natural Zeolite. Journal of Chemical Technology and Biotechnology, 80, 477-481. http://dx.doi.org/10.1002/jctb.1189

[74] Akgül, M., Karabakan, A., Acar, O. and Yürüm, Y. (2006) Removal of Silver (I) from Aqueous Solutions with Clinoptilolite. Microporous and Mesoporous Materials, 94, 99-104. http://dx.doi.org/10.1016/j.micromeso.2006.02.023

[75] Lihareva, N., Dimova, L., Petrov, O. and Tzvetanova, Y. (2010) $\mathrm{Ag}^{+}$Sorption on Natural and Na-Exchanged Clinoptilolite from Eastern Rhodopes, Bulgaria. Microporous and Mesoporous Materials, 130, 32-37. http://dx.doi.org/10.1016/j.micromeso.2009.10.009

[76] Haris, P.O. and Ramelow, G.J. (1990) Binding of Metal Ions by Particulate Biomass Derived from Chlorella vulgaris and Scenedesmus quadricauda. Environmental Science and Technology, 24, 220-228. http://dx.doi.org/10.1021/es00072a011

[77] Algarra, M., Jimenez, M.V., Rodriguez-Castellon, E., Jimenez-Lopez, A. and JimenezJimenez, J. (2005) Heavy Metals Removal from Electroplating Wastewater by Aminopropyl-Si MCM-41. Chemosphere, 59, 779-786. http://dx.doi.org/10.1016/j.chemosphere.2004.11.023

[78] Hanzlík, J., Jehlicka, J., Sebek, O., Weishauptová, Z. and Machovic, V. (2004) Multi-Component Adsorption of $\mathrm{Ag}(\mathrm{I}), \mathrm{Cd}(\mathrm{II})$ and $\mathrm{Cu}(\mathrm{II})$ by Natural Carbonaceous Materials. Water Research, 38, 2178-2184. http://dx.doi.org/10.1016/j.watres.2004.01.037

[79] Erdem, E., Karapinar, N. and Donat, R. (2004) The Removal of Heavy Metal Cations by Natural Zeolites. Journal of Colloid and Interface Science, 280, 309-314. http://dx.doi.org/10.1016/j.jcis.2004.08.028

[80] Zhanpeisov, N.U., Martra, G., Ju, W.S., Matsuoka, M., Coluccia, S. and Anpo, M. (2003) Interaction of $\mathrm{N}_{2} \mathrm{O}$ with $\mathrm{Ag}^{+}$Ion-Exchanged Zeolites: An FT-IR Spectroscopy and Quantum Chemical ab Initio and DFT Studies. Journal of Molecular Catalysis A: Chemical, 201, 237-246. http://dx.doi.org/10.1016/S1381-1169(03)00159-6

[81] Bogdanchikova, N.E., Petranovskii, V.P., Machorro, R.M., Sugi, Y., Soto, G.V.M. and Fuentes, M.S. (1999) Stability of Silver Clusters in Mordenites with Different $\mathrm{SiO}_{2} / \mathrm{Al}_{2} \mathrm{O}_{3} \mathrm{Mo}-$ lar Ratio. Applied Surface Science, 150, 58-64.

http://dx.doi.org/10.1016/S0169-4332(99)00223-8

[82] Yi, Y., Wang, Y. and Liu, H. (2003) Preparation of New Crosslinked Chitosan with Crown Ether and Their Adsorption for Silver Ion for Antibacterial Activities. Carbohydrate Polymers, 53, 425-430. http://dx.doi.org/10.1016/S0144-8617(03)00104-8

[83] Karabakan, A., Karabulut, S., Denizli, A. and Yürüm, Y. (2004) Removal of Silver(I) from Aqueous Solutions with Low-Rank Turkish Coals. Adsorption Science and Technology, 22, 135-144. http://dx.doi.org/10.1260/026361704323150917

[84] Tseng, R.L., Wu, F.C. and Juang, R.S. (2010) Characteristics and Applications of the Lagergren's First-Order Equation for Adsorption Kinetics. Journal of the Taiwan Institute of Chemical Engineers, 41, 661-669. http://dx.doi.org/10.1016/j.jtice.2010.01.014 
[85] Ho, Y.S. and McKay, G. (1999) Comparative Sorption Kinetic Studies of Dye and Aromatic Compounds onto Fly Ash. Journal of Environmental Science and Health, Part A, 34, 11791204. http://dx.doi.org/10.1080/10934529909376889

[86] Aksu, Z. (2001) Equilibrium and Kinetic Modeling of Cadmium(II) Biosorption by C. vulgaris in Batch System: Effect of Temperature. Separation and Purification Technology, 21, 285-294. http://dx.doi.org/10.1016/S1383-5866(00)00212-4

[87] Ho, Y.S. (1995) Adsorption of Heavy Metals from Waste Streams by Peat. University of Birmingham, Birmingham.

[88] Ho, Y.S., Wase, D.A.J. and Forster, C.F. (1996) Kinetic Studies of Competitive Heavy Metal Adsorption by Sphagnum Moss Peat. Environmental Technology, 17, 71-77. http://dx.doi.org/10.1080/09593331708616362

[89] Ho, Y.S. and McKay, G. (1998) A Comparison of Chemisorption Kinetic Models Applied to Pollutant Removal on Various Sorbents. Process Safety and Environmental Protection, 76, 332-340. http://dx.doi.org/10.1205/095758298529696

[90] Ho, Y.S. and McKay, G. (1998) Sorption of Dye from Aqueous Solution by Peat. Chemical Engineering Journal, 70, 115-124. http://dx.doi.org/10.1016/S0923-0467(98)00076-1

[91] Ho, Y.S. and McKay, G. (1999) Pseudo-Second Order Model for Sorption Processes. Process Biochemistry, 34, 451-465. http://dx.doi.org/10.1016/S0032-9592(98)00112-5

[92] Ho, Y.S. and McKay, G. (2000) The Kinetics of Sorption of Divalent Metal Ions onto Sphagnum Moss Peat. Water Research, 34, 735-742. http://dx.doi.org/10.1016/S0043-1354(99)00232-8

[93] Arica, M.Y., Kacar, Y. and Genc, O. (2001) Entrapment of White-Rot Fungus Trametes vesicolor in Ca-Alginate Beads: Preparation and Biosorption Kinetic Analysis for Cadmium Removal from an Aqueous Solution. Bioresource Technology, 80, 121-129. http://dx.doi.org/10.1016/S0960-8524(01)00084-0

[94] Wu, F.C., Tseng, R.L. and Juang, R.S. (2001) Kinetic Modeling of Liquid-Phase Adsorption of Reactive Dyes and Metal Ions on Chitosan. Water Research, 35, 613-618. http://dx.doi.org/10.1016/S0043-1354(00)00307-9

[95] Azizian, S. (2004) Kinetic Models of Sorption: A Theoretical Analysis. Journal of Colloid and Interface Science, 276, 47-52. http://dx.doi.org/10.1016/j.jcis.2004.03.048

[96] Ho, Y.S. (2004) Comment on "Kinetic Modeling and Equilibrium Studies during Cadmium Biosorption by Dead Sargassum sp. Biomass" by Cruz, C.C.V., da Costa, A.C.A., Henriques, C.A., Luna, A.S., Bioresource Technology, 91(3) (2004) 249-257. Bioresource Technology, 93, 321-323. http://dx.doi.org/10.1016/j.biortech.2003.11.008

[97] Ho, Y.S. (2004) Comments on "Arsenic Removal using Mesoporous Alumina Prepared via a Templating Method”. Environmental Science and Technology, 38, 3214-3215. http://dx.doi.org/10.1021/es049688w

[98] Ho, Y.S. (2004) Comments on "Removal of Copper from Aqueous Solution by Aminated and Protonated Mesoporous Aluminas: Kinetics and Equilibrium" by S. Rengaraj, Y. Kim, C.K. Joo, and J. Yi. Journal of Colloid and Interface Science, 276, 255-258. http://dx.doi.org/10.1016/j.jcis.2004.05.003

[99] Ho, Y.S. (2004) Comments on "Sorption of Basic Dyes from Aqueous Solution by Activated Sludge” [J. Hazard. Mater. 108 (2004) 183-188]. Journal of Hazardous Materials, 114, 241-245. http://dx.doi.org/10.1016/j.jhazmat.2004.08.019

[100] Ho, Y.S. (2004) Comments on "Cadmium Removal from Aqueous Solutions by Chitin: Kinetic and Equilibrium Studies”. Water Research, 38, 2962-2964.

http://dx.doi.org/10.1016/S0043-1354(03)00427-5 
[101] Ho, Y.S. (2004) Comments on "Collagen-Fiber-Immobilized Tannins and Their Adsorption of Au(III)". Industrial and Engineering Chemistry Research, 43, 6265. http://dx.doi.org/10.1021/ie0495877

[102] Justi, K.C., Laranjeira, M.C.M., Neves, A., Mangrich, A.S. and Fa'vere, V.T. (2004) Chitosan Functionalized with 2[-Bis-(pyridylmethyl)aminomethyl]4-methyl-6-formyl-phenol: Equilibrium and Kinetics of Copper(II) Adsorption. Polymer, 45, 6285-6290.

http://dx.doi.org/10.1016/j.polymer.2004.07.009

Submit or recommend next manuscript to SCIRP and we will provide best service for you:

Accepting pre-submission inquiries through Email, Facebook, LinkedIn, Twitter, etc.

A wide selection of journals (inclusive of 9 subjects, more than 200 journals)

Providing 24-hour high-quality service

User-friendly online submission system

Fair and swift peer-review system

Efficient typesetting and proofreading procedure

Display of the result of downloads and visits, as well as the number of cited articles

Maximum dissemination of your research work

Submit your manuscript at: http://papersubmission.scirp.org/

Or contact aces@scirp.org 